\title{
POSSIBLE ASPECTS OF OCCUPATIONAL AND PSYCHOLOGICAL ADAPTATION OF THE MILITARY, DISCHARGED FROM MILITARY SERVICE AND THEIR FAMILIES TO A NEW ACTIVITY LIFE CYCLE
}

\author{
Venelin Terziev \\ Corresponding Member of the Russian Academy of Natural History, Moscow, Russia, Prof. \\ D.Sc. (Ec.), D.Sc. (National Security), D.Sc. (Social Activities), Ph.D., National Military University, \\ Veliko Tarnovo, Bulgaria; University of Rousse, Rousse, Bulgaria, terziev@skmat.com
}

\begin{abstract}
Dynamic changes in the security environment put military personnel, discharged from service for one reason or another and their families to serious tests. Transiting from military to civilian social medium significantly changes their conditions of life, affecting various aspects of their lives, in the basis of which lie mentality and personality changes of every person, leaving their usual social medium and entering an unfamiliar one. Since research in this field is not so popular, authors of this paper are provoked to explore the factors affecting the mental state of modern Bulgarian servicemen transiting to reserves and their professional adaptation corresponding to the new living conditions and to identify the problem areas of their social and psychological adaptation.
\end{abstract}

Keywords: military personnel, discharged form service; social adaptation.

\section{INTRODUCTION}

The dynamic changes in the field of defence put military personnel, discharged for one reason or another from service and their family members to serious tests. Transitioning from military to civilian environment within the conditions of their lifecycle results in significant changes affecting various aspects of life: place of work and residence, living conditions, subject of activities, social status, level of aims in their new life, prospects for further development, social circle, etc. What makes impression is that the foundations of all these changes lay mainly in psychological and personality changes of the specific person leaving their typical social environment and transitioning to unwonted one.

Research in this field is not quite popular and that provoked our scientific inquiries in order to discover factors, affecting the mental state of modern Bulgarian military, transitioning to reserves and their professional adaptation, corresponding to new conditions of life. It is also the objective of this article.

Research in this direction point us to manifestation of several major groups of factors that predetermine the mental state of a service person discharged from military service. These include: the present state of the national economy; willingness of civil society to „accept” military in transition to reserves and their family 
members; level of commitment (attitude) of the Ministry of Defense to this population category; implemented social policies on behalf of the Ministry of Labour and Social Policy concerning this risk group on the labour market.

Their manifestation results in several major problems, defined as follows:

Problems resulting from radical change of the entire way of life: moving to a new place; deterioration of financial status; loss of home and uncertainty with respect to finding a home on the new place; problems with finding a job and need to adapt one's way of life to new conditions;

Problems, resulting from lack of guaranteed employment after discharge from military service, imperfections of vocational training and rehabilitation of military reserve, their job placement; insufficient practical implementation of privileges and rights of citizens, discharged from the Bulgarian Army;

Problems resulting from the fact that many of the military carry on previously stereotyped actions before and after being discharged, related to expecting assistance from the state; a habit to rely on formalized social protection of military structure;

Problems resulting from the unpreparedness to act in the conditions of the new economic situation within the country, loss of qualification by family members of military personnel; sustainably negative public image of discharged military in the opinion of employees of civil organizations employees;

Problems resulting from the fact that military institutions on various levels (except for Military Districts) openly ignore the needs of military personnel, discharged from service; unwillingness on behalf of the Ministry of Defense to take part in resolving their problems after discharge, etc.

Analysis shows that discharging from service leads to collapse of many hopes; loss of life and development perspectives for a significant part of the military personnel and members of their families. For people, who have devoted themselves to difficult military service from young age it is very hard to adapt to new conditions as a rule. Sociopsychological adaptation becomes a complex process for them. There occurs a necessity to pick up new social roles, to form new identity, allowing adequate self-perception, social environment, acquiring a new profession. Moreover, those difficulties accompany military personnel, discharged from service throughout the entire social adaptation process. They find it difficult to get on the right track in the world of civilian professions and sources of information, to compare their opportunities to the requirements to various types of labour, to find jobs and conclude employment contracts /to establish proper employment relations/.

As a result, people, able to make a worthy contribution to restructuring of society find themselves to be part of a socially unprotected category and constitute a risk group. Studies are indicative that up to $70 \%$ of the military reserve personnel experience serious difficulties when selecting a civilian profession /based on data, provided by the National Employment Agency /. Many of them remain unemployed for over a year. Besides finding a job for adequate entry to civilian life of discharged military personnel, they have to undertake a major and complex process of personal development: in many respects they need to change their concept of themselves; of their inner world and the surrounding world, to learn new behavioural strategies and tactics /new behavioural model/.

Discharged military personnel, unlike any other category of citizens need an adequate professional employment consultancy services on all matters, related to finding a job / employment services/, undergoing retraining /vocational rehabilitation/, adaptation to the employment market and a new workplace. Unfortunately this kind of training is not conducted in any of the military units and formations, neither in military district commands, based on residence, neither do public social services offer adequate program measures in this direction.

General and private technologies of social adaptation of military reservists and members of their families have been used for development and implementation of such projects within the Programme of Social Adaptation of Former Military Personnel. These include technologies of vocational orientation, psychological rehabilitation, socio-psychological rehabilitation, socio-pedagogical adaptation, attraction to small entrepreneurship, assistance to small entrepreneurship, finding a job, rehabilitation training and monitoring.

Major directions of psychological support are: psychological counselling, psycho correction, vocational orientation and psychotherapy, applying a wide-range methodologies and taking into account personality uniqueness, their problems within the context of the living situation; of the psychological support of entrepreneurial activities of military reserves, CEOs and assistants in SMEs. Psychologists carry out psychodiagnostics individual psychological counselling and psychotherapy, group psychotherapy, professional counselling, professional psychological recruitment, socio-psychological trainings focusing on 
various aspects, primary medical diagnostics.

Gathered experience, approbated consultation methodologies, collected wide-range statistical information in the course of implementation of the Social Adaptation Programme allow summarizing the major outcomes from psychological diagnostics of social problems of military personnel discharged from service. On those grounds it is possible to determine the dominating aspects within the structure of the psychological problems of military reservists and the members of their families. More specifically those are: vocational orientation and seeking job, unwillingness to undertake responsibility for one's living situation, partial psychological deadaptation, family conflicts, underdevelopment of communication skills, alcohol abuse, various addictions, adaptation neurotic reactions and neuroses.

The study of psychological problems of the researched category of military personnel and members of their families shows that discharge from military service is a painful moment for all family members. Major stressors for family members are: lack of jobs for spouses, lack of home, alcohol abuse by one of the spouses, financial difficulties, problems with children upbringing, divorce, lack of friends and relationships. As a result of these problems some of the most common psychological disorders in both children and adults are: apathies, depressions, fears, neuroses. Knowing these problems allows determination of the content of the socio-psychological support necessary to military personnel transferred to reserve.

Furthermore, an important aspect of the work in the psychological support field is the precise analyses of the entire prior experience and personal qualities of reservists, and taking a full account of them when seeking a proper job, or a vocational rehabilitation profile. Attention has been paid to the following characteristics of discharged military personnel: education level, vocational training profile, level of compliance of education with civilian work requirements, vocational qualities characteristics, and age.

Peacekeeping operations and special missions constitute a peculiar group of discharged military personnel. They usually have pronounced manifestations of posttraumatic stress disorder. The most common of them are: recurring vivid dreams and nightmares of combat situations, compulsive memories of psychotraumatic events, accompanied by traumatic experiences, sudden experiences, „reminiscent” of psychotraumatic situations, increased irritability, and gratuitous outbursts of anger. Many of these people lose interest in social life. They show little activity in solving their own vital problems. They often show loss of ability to emphasize and loss of the need of spiritual intimacy with other people, including within their family life. The life experience of those people is unique and differs sharply from the experience of people, who have not taken part in such missions. Memories and shared past bring participants together and make them seek each other. Moreover, not only service-disabled veterans need psychological help, but also their closest circle- parents, wife, children.

Experience shows that even today those families do not belong within the categories of families with special needs of protection and socio-psychological support.

Activity approbation in this field allows drafting a summarized model of the method of work with former military personnel and their families.

In the course of implementation of the Programme of Social Adaptation of Former Military Personnel attention should be paid to the fact that discharged military personnel need psychological support at all stages of their transition to civilian activity. Implementation of comprehensive approach to this activity requires solving problems related to:

- Timely preparation for discharging from service and transition to civilian activity;

- informing military reservists about the transition period regularities, about the peculiarities on the employment market and professional activity under civilian conditions, about what difficulties to expect; • being psychologically ready for change of a professions and sustainability in critical situations; - selection of a new profession, similar to prior activity;

- Patterns in applying the simplest methods and ways to reduce mental strain and stress conditions;

- Preparations of behavioural strategies and tactics on the employment market.

Experience shows that the greatest outcomes of psychological adaptation of military personnel is achieved by specialists, where systematic and planned work is implemented with a view of the specific character of transition stages of military reservists and the members of their families to the new conditions of civilian life. For this reason, following the logic of our research to pay attention to those specific stages (Terziev, 2017; Terziev, 2017a, pp.1375-1399; Terziev, 2017b, pp.1362-1377; Terziev, 2017c, pp.1378-1392; Terziev, 2017d, pp.1352-1361; Terziev, 2017e, pp.914 - 922; Terziev, 2017f, pp. 923 - 935; Terziev, 2017g, pp.49-59; 9. Terziev, 2017h, pp.452-458; Terziev, 2017i, pp.786-796; Terziev, 2017j, pp. 997-1024; Terziev, 
Bogdanov, Madanski, Stefanov, 2017k, pp.85-97; Banabakova, Georgiev, 2017l, pp. 46-51; Banabakova, Georgiev, 2017m, pp. 462-467; Banabakova, Georgiev, 2017n, pp. 84-99; Banabakova, Georgiev, 2017o, pp. 468-483; Terziev, Madanski, Georgiev, 2017p, pp. 923-927; Terziev, Madanski, Georgiev, 2017q, pp. 1051-1055; Terziev, Nichev, Stoyanov, Georgiev, 2017r, pp. 888-892; Banabakova, Georgiev, 2017s, pp. 37-47).

\section{PREPARATION STAGE FOR DISCHARGE FROM MILITARY SERVICE}

The stage time framework coincides with the activities for preparation of military personnel for discharge. Rehabilitation and adaptation activities shall be carried out at the place of work and residence of the military personnel and their families. At this stage the activity is mainly focused on preparation for future discharge. Here it is important to help every serviceperson realize that leaving the army is a logical and natural step in their work experience. An important point is to reduce possible insult, to keep capability to objectively evaluate the situation. The goal of specialists at this point is to raise the awareness of military personnel of civilian activity, employment market, and their professional abilities. Training seminars are carried out in groups by psychologists and professional consultants. Reaching the necessary level of readiness for a change of the profession of the serviceperson to be discharged is an outcome of the activity carried out. It allows reducing excessive mental strain and aggression in subsequent adaptation stages.

\section{PROFESSIONAL PREPARATION STAGE}

Mental readiness for change of profession is a human condition, characterized by stage of formation of a number of personal qualities that influence the efficiency of vocational orientation, as well as with the presence of certain knowledge, habits and skills concerning professional activity. We are speaking not quite of readiness for successful work in one or another new profession, but for readiness for the process of reorientation as a specific activity, related to gathering of information about the employment market, studying one's abilities, acquiring new knowledge and working habits and searching for optimal workplace.

The purpose of the psychological support at this stage is to determine the degree of compliance of serviceperson's personal qualities with the requirements of the future specialty, ensuring rightness of choice of educational profile and facility. Psychodiagnostic activities of serviceperson's professional interests and skills are carried out, specific recommendations for purposeful development of mental qualities of professional importance for the future activity are drafted. As important is the provision of support in organization and solidification of new knowledge with the purpose of adaptation to the training process.

It is appropriate to carry out career orientation activities, allowing not to spend time and money in vain and to start training in selected profession. The most popular methods and forms of career orientation activities are:

- Specially organized monitoring of people and career orientation interpretation of the outcome of their activity;

- Carrying out career orientation consults (interview); • use of tests and other psychodiagnostic methods for studying the interests, aptitudes, personal qualities and features of a serviceperson;

- implementing game and training methods and means for activation a career choice;

- Use of special equipment and simulators for developing working habits and studying one's readiness to pick up new professional activities;

- Dissemination of awareness literature, information about jobs on the regional employment market;

- Studying professional graphic material on various specialties, on telecommunication networks resources.

In the initial stage of organization of provision of psychological support to former military personnel and the members of their families psychology specialists are given the task to overcome the standard error of overestimating the role of test methodologies in psychocorrectional work, to change adaptation activities with diagnostic ones. In order to avoid such a "distortion" of consultants' activity, their attention should be pointed at: diagnostic procedures development, including the necessary and sufficient quantity of tests, to be used by specialists in the primary support stage; at training specialists in testing methodologies; at processing test material with computing equipment; at training psychologies in contemporary methods of provision of psychological support.

An important role in career orientation of military personnel is played by group forms of psychological work, such as training seminars that allow overcoming and reducing social construct influences, hampering adaptation; to reduce the relative rigidity, typical for them; to change one's pessimistic idea of themselves and surrounding reality; to form an aspiration to actively participate in life within the new conditionc. 
Such training seminars allow solving social and educational tasks, namely: to show possible directions of creative capabilities within the conditions of the new social medium; to confirm the compliance of basic professional habits to the needs of the future activity; to demonstrate one's capabilities to keep their high social status in civilian life; to specify the fields of rational use of ones strengths and activity under the new conditions, etc.

Psychological assistance in the process of preparation is an important component of the social and psychological adaptation of military reservists, because it is focused on the formation of self - regulation and control on one's behaviour, and contributes to formation of personal activity at the employment placement stage.

\section{EMPLOYMENT PLACEMENT STAGE}

At this stage support to military personnel consists of joint (together with the military) evaluation of their willingness to look for a job. In the course of the search for a job it is important for the military reservist to keep persistence and self-confidence, especially after several refusals for employment placement, to exclude unjustified transition from naïve optimism to total pessimism. They should be aware of their strengths and consistently to search for "their" job, and at the same time to be ready for temporary compromise when selecting a job, due to the situation on the employment market. Expert psychologists explain that searching for a job is also a job, and make military personnel aware of existing technologies for effective job search.

\section{STAGE OF PICKING UP THE NEW ACTIVITY}

At this stage it is necessary to show the serviceperson that finding a job does not mean that problems of entering civilian life have been solved. They are now facing a continuous and controversial process of picking up new duties and new system of relations within the civilian social environment, which is not constituted the same way as the military one. The transition to a new system of relations is always difficult and especially at mature age. Military personnel should be ready for serious difficulties on their way, often accompanied by change of a number of habits and strict self-control.

In this period psychologists and career orientation specialists help military reservists establish relationships with their colleagues and superiors, select proper behaviour and manner of interaction with people around, overcome difficulties, arising while picking up a new profession, not lose heart upon unsuccessful start. Their role is to help understand that under the conditions of market relations the willingness for changing jobs should be persistent.

Major goals /for evaluation / are:

Evaluation of social self-confidence of military, taking part in combat activities;

Identification of the range of problems that former military personnel face after leaving Armed forces (social, mental, domestic etc.);

Analyses of the satisfaction of military personnel with their social status and the correlation with public opinion etc;

Evaluation of the degree of post-traumatic stress disorders, resulting from participation in military missions;

Forecasting major approaches of work with them with respect to psychological and medicopsychological rehabilitation and social adaptation.

The purpose of such a project is establishing a comprehensive system of medical, psychological and social rehabilitation of military personnel transitioning to reserve. A rehabilitation actions system is established with their participation, in order to achieve psychical equilibrium recovery and recovery of the complex psychological reactions of military personnel, who have taken part in hostilities, in compliance with the requirements of the social environment. The system includes:

Psychodiagnostics of current mental conditions:

Recovery of mental activity;

Recovery of individual and psychological characteristics;

Strengthening psychological reactions and personal characteristics within the normal;

Attraction of the person within the social interactions system, social activity development.

In the course of the practical work in psychodiagnostics and provision of psychological support one 
circumstance hampering the implementation of the project objectives and project tasks is the lack of understanding on behalf of many military of the fact that psychological support is necessary. The most common reason is due to fear to get psychiatric diagnosis, because many of them associate psychological support with psychiatric treatment. In this respect, it is useful to clarify the essence and nature of the psychological consequences of war, their logical nature at the subsequent adaptation stage and the nature and scope of the possible psychological support.

In this way as an important outcome, requiring respective corrective measures of subsequent social adaptation of military on active service, conclusions have been drawn, about the fact that post-traumatic disorders develop after returning to typical living situation after being in extreme environment. At this stage in particular very often there is additional psychological traumatizing and the typical so called normal conditions of peaceful life for many military, who have taken part in hostilities they become source of stress and negative psychological changes.

Explanation of the mentioned phenomenon shall be sought in the special characteristics of the social environment that military reservists face at the social adaptation phase, in particular if they have taken part in hostilities. The social environment itself turns into a major factor for the successful rehabilitation and viceversa.

A person with military past, life experience out of the typical human experience, after returning to civilian life, remains alone with their problems. The natural human desire to share one experience or another with someone, the need for empathy remain unmet because according to their subjective opinion those experiences would not be fully perceived and understood.

The exclusion of military personnel transferred to reserve from the social interactions system in their social environment, i.e. destruction of the established group, of those relations that have been developed in the extreme environment, when those interactions mean more that all other values in life, has a psychogenic character and when combined with other factors results in social and psychological personality deadaptation.

The feeling of meaninglessness and uselessness of all experiences while on service, at war, during combat, the guilt, because they have survived are factors determined by social opinion and attitude towards the objectives, tasks and balance of the specific armed conflict.

The family situation when loved ones are often subject to traumatic stress and need psychological support and rehabilitation, continuous expectation of the worst to happen with a loved one at war naturally causes specific mental changes.

The implementation of social adaptation comprehensive model for former military personnel and members of their families is done following various directions, one of which is their pre-qualification in specific professions as required by the region of residence. This direction becomes dominant in the social adaptation system of the Bulgarian army.

This means that the serviceperson might need to undergo training in civilian occupational specialties:

During service, before transfer to reserve or resignation;

Before discharge from military service- upon pre-qualification at a specialized training centre;

Several years before discharge - extramural or distance course at a university;

After discharge from military service and moving to e permanent residence, before job placement;

After job placement at a company depending on their professional qualification at industry and other vocational training centres or on job site.

Special courses shall be developed, module courses should be implemented and specialized training centres should be established, etc for implementation of educational programmes for prequalification and raising the qualification of military reservists and members of their families. The process of prequalification of former military personnel shall be continuously perfected in accordance with the requirements of the Bulgarian army.

\section{CONCLUSION}

In conclusion the studied activity could be evaluated in general as significant, meaningful, and important but not a priority within the social adaptation system of former military and members of their families. Studying this course of work and the experience in other state shows that prequalification is important, but only one element of the adaptation process, that if former military obtain new profession it will not solve their 
problems. Moreover even the current system for their pre-qualification is not free of significant drawbacks.

The major disadvantage of such an approach is in the fact that the requirement of the known didactic principle - for individual and group approach has not been implemented. This approach does not suppose differences in professional pre-qualification of former military physician, military financier, military teacher of humanities and some other categories of officers for whom such training is unnecessary as a rule.

Also, existing analyses shows that interest of every civilian educational institution to problems of prequalification of former military personnel consists mainly in raising funds for organizing prequalification of all population categories. Problems of adaptation to new conditions of life, job placement with maximum benefit for regional development are not related to educational institutions, because those functions are not typical to the latter.

Therefore, knowing psychological and professional aspects of former military personnel adaptation and their families without claiming to know them in full is the foundation for establishing a social adaptation methodology, reflecting the aspect herein studied and reaching a life balance by the studied category in compliance with the new conditions of life (Terziev, Madanski, Georgiev, 2017t, pp. 748-753; Terziev, Madanski, Georgiev, 2017u, pp. 743-747; Madanski, Georgiev, 2017v, pp. 4-13; Madanski, Georgiev, 2017w, pp. 43-51; Terziev, Dzhumalieva, 2016a, s.233-253; Terziev, 2014, s.176-183; Terziev, 2014a, s.183-191; Terziev, 2014b, s.192-204; Terziev, 2014c, pp.194-201; Terziev, 2014d, s.201-210; Terziev, 2014e, s.210-222).

\section{REFERENCE LIST}

Terziev, Venelin. (2017). Opportunities for improving the efficiency of the socialadaptation of servicemen discharged from military service in Bulgaria. // Catalogue of the scientific, educational and methodical literature presented by authors at the I-XXXIV All-Russian book exhibitions held by Academy of Natural History, Exposition on the Frankfurter Buchmesse 2017, XXVII, Moskow, Academy of Natural History, 2017.

Terziev, Venelin. (2017a). Social adaptation as a social process in the adaptation of military personnel. // Journal of Economic Geography, International Health, Oxford University Press, 17, 2017, N 6(2), pp.1375-1399, ISSN 1468-2702.

Terziev, Venelin. (2017b). Insights into some examples of triggering the process of social adaptation. // International Health, Oxford University Press, 9, 2017, N6 (2), pp.1362-1377, ISSN 1876-3413.

Terziev, Venelin. (2017c). Examples of modelling social adaptation of servicemen discharged from military service. // International Health, Oxford University Press, 9, 2017, N 6 (2), pp.1378-1392, ISSN 18763413.

Terziev, Venelin. (2017d). Studying different aspects of social adaptation. // International Health, Oxford University Press, 9, 2017, N6 (2), pp.1352-1361, ISSN 1876-3413.

Terziev, Venelin. (2017e). Social adaptation and socialization as processes: characteristics, principles, factors. // European Journal of International Law, Oxford University Press, 28, 2017, N 4 (2), pp.914 922, ISSN 0938-5428.

Terziev, Venelin. (2017f). Factors affecting the process of social adaptation. // European Journal of International Law, Oxford University Press, 28, 2017, N 4 (2), pp. 923 - 935, ISSN 0938-5428.

Terziev, Venelin. (2017g). A new view on social adaptation of the military, discharged from military service in Bulgaria. // IJASOS- International E-Journal of Advances in Social Sciences, April 2017, 3, 2017, N 7, ISSN 2411-183X, pp.49-59.

Terziev, Venelin. (2017h). Factors affecting the process of social adaptation. // $3^{\text {rd }}$ International Conference on Advanced Research in Business and Social Sciences 2017 29th to $30^{\text {th }}$ March, 2017, 1, 2017, ISBN: 978-967-13620-2-0, pp.452-458.

Terziev, Venelin. (2017i). A New View on Social Adaptation of the Military, Discharged From Military Service in Bulgaria. // Intcess 2017, 4th International conference on education and social sciences, 6-8 February, 2017 - Istanbul, Turkey, 2017, ISBN 978-605-64453-9-2, pp.786-796.

Terziev, Venelin. (2017j). A new view on social adaptation of the military, discharged from military service in 
IJASOS- International E-Journal of Advances in Social Sciences, Vol. IV, Issue 12, December 2018

Bulgaria. // Oxford Review of Economic policy, 33, 2017, N 4 (2), pp. 997-1024, ISSN 0266-903X.

Terziev, V., Bogdanov, P., Madanski, V., Stefanov, S. (2017k). Approaches to social adaptation of servicemen discharged of military service. // Eight international scientific conference Knowledge without borders, 8-10 април 2016 г., Банско, България. International Journal Scientific papers, 12, 2016, N 2, ISSN1857-92, pp.85-97.

Banabakova, V., Georgiev, M. (2017l). Military professional forming of the cadets at Vasil Levski National Military University. // IJAEDU- International E-Journal of Advances in Education, April 2018, Turkey, International Organization Center of Academic Research, www.ocerints.org, Istanbul, Turkey, 2018, pp. 46-51, 4, 2018, N 10, e-ISSN: 2411-1821.

Banabakova, V., Georgiev, M. (2017m). Military professional forming of the cadets at Vasil Levski National Military University. // Proceedings of INTCESS2018- 5th International Conference on Education and Social Sciences 5-7 February 2018- Istanbul, Turkey, International Organization Center of Academic Research, www.ocerints.org, Istanbul, Turkey, 2018, pp. 462-467, ISBN: 978-605-82433-2-3.

Banabakova, V., Georgiev, M. (2017n). The role of the Balanced Scorecard as a tool of strategic management and control. // IJAEDU- International E-Journal of Advances in Education, April 2018, International Organization Center of Academic Research, www.ocerints.org, Istanbul, Turkey, 2018, pp. 84-99, 4, 2018, N 10, e-ISSN: 2411-183X.

Banabakova, V., Georgiev, M. (20170). The role of the Balanced Scorecard as a tool of strategic management and control. // Proceedings of INTCESS2018- $5^{\text {th }}$ In-ternational Conference on Education and Social Sciences 5-7 February 2018- Istanbul, Turkey, International Organization Center of Academic Research, www.ocerints.org, Istanbul, Turkey, 2018, pp. 468-483, ISBN: 978-605-824332-3.

Terziev, V., Madanski, V., Georgiev, M. (2017p). Offset implementation impact on technology transfer in Bulgaria. // IJAEDU- International E-Journal of Advances in Education, International Organization Center of Academic Research, www.ocerint.org, 3, 2017, N 9, pp. 923-927, e-ISSN: 2411-18.

Terziev, V., Madanski, V., Georgiev, M. (2017q). Offset as an economic operation and a trade practice. // IJAEDU- International E-Journal of Advances in Education, International Organization Center of Academic Research, www.ocerint.org, 3, 2017, N 9, pp. 1051-1055, e-ISSN: 2411-18.

Terziev, V., Nichev, N., Stoyanov, E., Georgiev, M. (2017r). A general principle of the development process of Balanced scorecards as an instrument of control. // IJAEDU- International E-Journal of Advances in Education, International Organization Center of Academic Research, www.ocerint.org, 3, 2017, N 9, pp. 888-892, e-ISSN: 2411-18.

Banabakova, V., Georgiev, M. (2017s). Problems and perspectives in Military professional education and realization of cadets in Bulgaria. // Journal of Innovations and Sustainability, Innovations and Sustainability Academy. 3, 2017, N 4, pp. 37-47, ISSN 2367-8127 (CD-ROM), ISSN 2367-8151 (online).

Terziev, V., Madanski, V., Georgiev, M. (2017t). Offset as an economic operation and a trade practice. // Proceedings of ADVED 2017- 3rd International Conference on Advances in Education and Social Sciences 9-11 October 2017- Istanbul, Turkey. International Organization Center of Academic Research, www.ocerint.org, 2017, pp. 748-753, ISBN: 978-605-82433-0-9.

Terziev, V., Madanski, V., Georgiev, M. (2017u). Offset implementation impact on technology transfer in Bulgaria. // Proceedings of ADVED 2017- 3rd International Conference on Advances in Education and Social Sciences 9-11 October 2017- Istanbul, Turkey. International Organization Center of Academic Research, www.ocerint.org, 2017, pp. 743-747, ISBN: 978-605-82433-0-9.

Madanski, V., Georgiev, M. (2017v). The offset as a specific sort of economic activity. // Scientific journal «Economics and finance». Academic publishing house of the Agricultural University, Priority research areas: Collection of scientific articles, 2017, pp. 4-13, ISBN 978-617-7214-53-2.

Madanski, V., Georgiev, M. (2017w). Study of the effect of offset implementation on technology transfer in the Republic of Bulgaria. // Scientific journal «Economics and finance». Academic publishing house of the Agricultural University, Priority research areas: Collection of scientific articles, 2017, pp. 43-51, ISBN 978-617-7214-53-2.

Terziev, V., Dzhumalieva, A. (2016a). Dostapnost do pazara na truda i sotsialna adaptatsiya na osvobodenite ot balgarskata armiya voennosluzheshti i chlenovete na tehnite semeystva. // XI 
Mezhdunarodnoy nauchnoy konferentsii „Innovatsii v tehnologiyah i obrazovanii", 18-19 Marta 2016 g., Kuzbasskiy gosudarstvennayy tehnicheskiy universitet im. T.F. Gorbacheva, Belovo, 4, 2016, ISBN 978-5-906888-04-4, s.233-253 (Терзиев, В., Джумалиева, А. Достъпност до пазара на труда и социална адаптация на освободените от българската армия военнослужещи и членовете на техните семейства. // XI Международной научной конференции „Инновации в технологиях и образовании", 18-19 Марта 2016 г., Кузбасский государственный технический университет им. Т.Ф. Горбачева, Белово, 4, 2016, ISBN 978-5-906888-04-4, с.233-253).

Terziev, Venelin. (2014). Possible aspects of occupational and psychological adaptation of the military, discharged from military service and their families to a new activity life cycle. // Mezhdunarodnaya nauchno-prakticheskaya konferentsiya "Nauka XXI veka: teoriya, praktika, perspektivay”, 6 lyunya 2014, Ufa, Rossiya, 2014, ISBN 978-5-906763-30-3, s.176-183 (Terziev, Venelin. Possible aspects of occupational and psychological adaptation of the military, discharged from military service and their families to a new activity life cycle. // Международная научно-практическая конфреренция „Наука XXI века: теория, практика, перспективы", 6 Июня 2014, Уфра, Россия, 2014, ISBN 978-5-90676330-3, c.176-183).

Terziev, Venelin. (2014a). Realities of implementing the social adaptation procees of military personnel, discharged form service in Bulgaria. // Mezhdunarodnaya nauchno-prakticheskaya konferentsiya „Nauka XXI veka: teoriya, praktika, perspektivay”, 6 lyunya 2014, Ufa, Rossiya, 2014, ISBN 978-5906763-30-3, s.183-191 (Terziev, Venelin. Realities of implementing the social adaptation procees of military personnel, discharged form service in Bulgaria. // Международная научно-практическая конфреренция „Наука XXI века: теория, практика, перспективы”, 6 Июня 2014, Уфа, Россия, 2014, ISBN 978-5-906763-30-3, c.183-191).

Terziev, Venelin. (2014b). Bulgarian experience in the development of social adaptation of military personnel, discharged from military service and their families. // Mezhdunarodnaya nauchnoprakticheskaya konferentsiya „Nauka XXI veka: teoriya, praktika, perspektivay”, 27 lyunya 2014, Ufa, Rossiya, 2014, ISBN 978-5-906763-30-3, s.192-204 (Terziev, Venelin. Bulgarian experience in the development of social adaptation of military personnel, discharged from military service and their families. // Международная научно-практическая конференция „Наука XXI века: теория, практика, перспективы”, 27 Июня 2014, Уфа, Россия, 2014, ISBN 978-5-906763-30-3, с.192-204).

Terziev, Venelin. (2014c). Possible aspects of occupational and psyhological adaptation of the military, discharged from military service and their families to a new activity life cycle. // Международная научно-практическая конференция: 27 Июня 2014, „Наука и Современность”, Уфа, Россия, 2014, ISBN 978-5-906763-48-8, pp.194-201 (Terziev Venelin. Possible aspects of occupational and psyhological adaptation of the military, discharged from military service and their families to a new activity life cycle. // Mezhdunarodnaya nauchno-prakticheskaya konferentsiya: 27 lyunya 2014, „Nauka i Sovremennosty”, Ufa, Rossiya, 2014, ISBN 978-5-906763-48-8, pp.194-201).

Terziev, Venelin. (2014d). Realities of implementing the social adaptation process of military personnel, discharged from service in Bulgaria. // Международная научно-практическая конференция 27 Июня 2014, „Наука и Современность”, Уфа, Россия, 2014, ISBN 978-5-906763-48-8, с.201-210 (Terziev, Venelin. Realities of implementing the social adaptation process of military personnel, discharged from service in Bulgaria. // Международная научно-практическая конференция 27 Июня 2014, „Наука и Современность”, Уфра, Россия, 2014, ISBN 978-5-906763-48-8, с.201-210).

Terziev, Venelin. (2014e). Bulgarian experience in the development of social adaptation of military personnel, discharged from military service and their families. // Mezhdunarodnaya nauchnoprakticheskaya konferentsiya 27 Iyunya 2014, „Nauka i Sovremennosty”, Ufa, Rossiya, 2014, ISBN 978-5-906763-48-8, s.210-222 (Terziev, Venelin. Bulgarian experience in the development of social adaptation of military personnel, discharged from military service and their families. // Международная научно-практическая конференция 27 Июня 2014, „Наука и Современность”, Уфра, Россия, 2014, ISBN 978-5-906763-48-8, c.210-222). 